УДК: 658

Битов В.П., к.е.н., доцент

Кадебська Е.В., к.е.н.

Волинський інститут ім.В.Липинського МАУП

\title{
МЕТОДИ УПРАВЛІННЯ ЯК СПОСІБ ВПЛИВУ В ДОСЯГНЕННІ ЦІЛЕЙ ПІДПРИЕМСТВА
}

У публікації розглянуто роль і значення надзвичайно важливого в економіці виробництва процесу управління, що означає за науковим визначенням менеджмент, а також способи впливу на окремих робітників та виробничі колективи в цілому, для досягнення цілей розвитку підприємства. Управління - це сукупність способів і прийомів впливу на колектив працівників та окремих виконавців з метою досягнення встановлених цілей. За їх допомогою орган управління впливає на окремих працівників і підприємство у цілому. Значення методів управління визначає їхню спрямованість на досягнення цілей у найбільш стислі строки за умов раціонального використання всіх видів ресурсів. Адже як відомо, що сьогодні виробництво відіграє в житті суспільства і кожної окремої людини дуже важливу роль і є невід'ємною складовою людського життя, вона охоплює людські ресурси, ії здібності та виробничий досвід. Як відомо виробництво сьогодні розв'язує складні завдання, що орієнтовані на зростаючі потреби людей, а тому все досконалішим має бути управління як метод впливу на досягнення ефективних результатів діяльності господарюючих формувань. У публікації відображено окремі позитивні приклади використання ефективних методів управління в сільгосппідприємствах Волинської області.

Ключові слова: управління, праця, ефективність, підприємництво. підприємець, ринкова економіка, прибуток, кошти, ресурси, підприємницький ризик,менеджмент.

Bitov V., Kadebskaya E.

\section{MANAGEMENT METHODS AS A WAY OF INFLUENCING THE ACHIEVEMENT OF THE GOALS OF THE ENTERPRISEЮ}

The publication examines the role and importance of extremely important in the production economy of the management process, which means scientifically defined management, as well as ways to influence individual workers and production teams in general, to achieve the goals of enterprise development. Management is a set of ways and techniques of influencing the staff of employees and individual contractors in order to achieve the set goals. With their help, the management body influences individual employees and the enterprise as a whole

The importance of management methods determines their focus on achieving goals in the shortest time possible under the rational use of all types of resources. It is well known that today production plays a very important role in the life of society and every individual and is an integral part of human life, it covers human resources, its abilities and production experience. Manufacturing is known today to meet the challenges of growing demand therefore, management should be increasingly improved as a method of influencing the achievement of effective results of economic entities. The publication presents some positive examples of the use of effective management methods in agricultural enterprises of the Volyn region.

Keywords: management, labor, efficiency, entrepreneurship. entrepreneur, market economy, profit, money, resources, entrepreneurial risk, management.

Бытов В.П., Кадебская Э.В.

\section{МЕТОДЫ УПРАВЛЕНИЯ КАК СПОСОБ ВЛИЯНИЯ В ДОСТИЖЕНИИ ЦЕЛЕЙ ПРЕДПРИЯТИЯ}

В публикации рассмотрены роль и значение важнейшего в экономике производства процесса управления, что означает по научным определением менеджмент, а также способы воздействия на отдельных рабочих и производственные коллективы в целом, для достижения целей развития предприятия. Управление - это совокупность способов и приемов воздействия на коллектив работников и 
отдельных исполнителей с целью достижения установленных целей. С их помощью орган управления влияет на отдельных работников и предприятие в целом. Значение методов управления определяет их направленность на достижение целей в кратчайшие сроки в условиях рационального использования всех видов ресурсов. Ведь не секрет, что сегодня производство играет в жизни общества и каждого отдельного человека очень важную роль и является неотъемлемой составляющей человеческой жизни, она охватывает человеческие ресурсы, его способности и производственный опыт. Как известно производство сегодня решает сложные задачи, ориентированные на растущие потребности людей, а потому все более совершенным должно быть управление как метод влияния на достижение эффективных результатов деятельности хозяйствующих формирований. В публикации отражено отдельные положительные примеры использования эффективных методов управления в сельхозпредприятиях Волынской области.

Ключевые слова: управление, труд, эффективность, предпринимательство. предприниматель, рыночная экономика, прибыль, средства, ресурсы, предпринимательский риск, менеджмент.

Постановка проблеми у загальному вигляді та іï зв'язок 3 важливими науковими і практичними завданнями. Сьогодні методи управління, як дієвий спосіб впливу у забезпеченні ефективних результатів господарювання набирають все більшого застосування у практичній діяльності підприємств. Адже умови ринку є такі, що вимагають від господарюючих підприємств застосування впливових і результативних методів управління, які б забезпечили успішне виробництво та прибуток від результатів праці. На нашу думку особлива увага повинна приділятися повноцінному аналізу щодо отриманих результатів від впроваджених комплексу заходів управлінського впливу. Вбачаємо, що на часі проводити як дослідження так і вивчення практичного досвіду господарюючих підприємств для поширення його і впровадження. Дослідники i науковці вивчаючи питання управління як сукупність способів і прийомів впливу на колектив працівників та окремих виконавців з метою досягнення встановлених цілей стверджують, що виробництво сьогодні розв'язує складні завдання, які орієнтовані на зростаючі потреби людей, а тому все досконалішим має бути управління як метод впливу на досягнення ефективних результатів діяльності господарюючих формувань.

Аналіз останніх досліджень і публікацій, у яких започатковано вирішення проблеми. Щодо аналізу останніх досліджень і публікацій то слід відмітити, що управлінню і його методів, що забезпечують вагомий вплив на успішний розвиток підприємств і підприємництва здавна і сьогодні привертає увагу дослідників. Наука управління як цілісна система із своїм категорійним апаратом, принципами, методологією, рекомендаціями виникла лише у XX ст. В iї основу була покладена концепція «раціональної бюрократії», яка відводила велику роль у забезпеченні ефективності управління формуванню ієрархічних структур, розподілу управлінської праці, чіткому визначенню посадових обов'язків і встановленню відповідальності менеджерів за їх виконання. Зокрема у роботах А. Файоля М. Вебера, управління розглядається як у загальнотеоретичному, так і в практично-функціональному плані. Значний вклад по вивченню питань щодо методів управління та їх впливу на підвищення результатів діяльності підприємств у виробничій сфері в Україні вносять сучасні автори - Вербова О.С.,Чуткий А.І, Струк Н.П. Ковальська Л.Л. Радіонова Ф. та ін. Названі та інші вчені чимало зробили для пропаганди передового досвіду з проблем організації управління та забезпечення зростання ефективності виробничих процесів на підприємстві. Однак, слід зазначити, що досі недостатньо вивчений єдиний погляд на питання дієвих методів організації управління, адже як відомо окремі господарюючі колективи не забезпечують бажаних результатів своєї праці, що і власне визначає мету даної публікації.

Цілі статті. Мета статті полягає у розкритті сутності та визначенні різних підходів та методів управління у виробничій сфері, як впливовий і дієвий важіль у досягненні цілей підприємства, а також його значення і роль в сучасному ринку. У даній публікації 
показані на наш погляд основні існуючі методи в управлінні, що діють в сучасній економіці i зокрема в досліджених нами сільськогосподарських підприємствах Волинської області. Відображено значимість і роль методів управління, а також дієвість у забезпеченні певних результатів в сучасному підприємстві та розв'язанні соціальних і економних проблем суспільства.

Виклад основного матеріалу дослідження 3 повним обгрунтуванням отриманих наукових результатів. Дана публікація про методи управління як спосіб впливу в досягненні цілей підприємства обрана нами з метою показати, що саме управління і відповідні методи його $\epsilon$ особливо важливими для забезпечення відповідних результатів господарської діяльності підприємств. В даній статті хочемо висвітлити як наукові погляди 3 приводу застосування відомих у практиці методів управління, а також показати окремі приклади результатів вмілого застосування методів управління і зокрема сукупності економічних, організаційно-господарських та інших впливових методів в сільськогосподарських підприємствах Волинської області. Як відомо, що методи управління сьогодні є різні і в тому числі як дослідженні на практиці, а також і ні. Однак їх сукупність в результаті впливу на колектив працівників та окремих виконавців забезпечує певні результати у досягненні встановлених цілей. Інакше і бути не може, адже за допомогою застосування методів управління впливає на окремих працівників і підприємство у цілому, в тому числі і в питаннях добору i розстановки кадрів. Адже за науковим визначенням управлінські методи своєю головною метою сьогодні ставлять свою спрямованість на досягнення намічених цілей i досягнення ефективних результатів та здобутків, а також в пріоритеті їх знаходиться забезпечення раціонального використання всіх видів використовуваних у практичній діяльності ресурсів. Виходячи з цього в даній публікації хочемо розглянути певні групи методів які на наш погляд $є$ найбільш впливовими і результативними. До таких методів управління хочемо віднести і показати в публікації насамперед такі як економічні методи, що охоплюють питання планування, обліку, комерційного розрахунку, встановлення цін на товари і послуги, а також організаційно-адміністративні методи управління. Адже як свідчить практика діяльності сільськогосподарських підприємств Волинської області, що завдяки впровадженню сукупності випробуваних ефективних методів управління сільськогосподарські підприємства разом з харчовою промисловістю за 10 місяців 2019 року забезпечили більше 30\% валового внутрішнього продукту області. За згаданий період, а саме 10 місяців 2019 року аграрні підприємства виробили продукції на 7 млрд. гривень. Частка Волинського внеску у загальній складовій ВВП України за згаданий період становить 3\%.

Незаперечним $є$ той факт, що методи управління грунтуються на дії економічних факторів ринкової економіки, їм належить провідне місце в системі методів управління господарською діяльністю організацій, вони сьогодні посідають найважливіше місце в системі методів управління.[7.с.76] Це зумовлене тим, що управлінські відносини визначаються насамперед економічними відносинами, в основу яких покладено об'єктивні потреби й інтереси людей. Адже тут закладені принципи мотивації праці, через ефективні системи оплати праці та відповідні заохочувальні мотиви, а також принципи планування витрат і здобутків, ціноутворення на продукти праці і послуги, комерційний розрахунок і економне ставлення до використовуваних ресурсів та ін. Тому нами вбачається, що якраз така сукупність управлінських важелів, а також забезпеченість підприємства трудовими ресурсами та при цьому їх раціональне використання забезпечить збільшення обсягів виробництва продукції, зниження іiі собівартості та збільшення прибутку, що і забезпечує досягнення цілей підприємства в його розвитку. 
Щодо зокрема економічного методу планування. Вивчаючи даний метод, наші дослідження свідчать, що даний метод є досить важливим, адже він передбачає планування розвитку підприємства і його окремих галузей виключно на розрахунковій основі, яка б в кінцевому результаті передбачала прибуток. Тобто підприємство розробляючи бізнес-план повинно передбачати обов'язково обсяги виробництва i канали просування продукції до споживача, передбачити також питання забезпечення матеріальними ресурсами, проаналізувати кадровий потенціал, організаційно правові моменти та ін. Наші дослідження з питань планування свідчать про широке і ефективне застосування у практичній діяльності даного методу в більшій частині сільськогосподарських підприємств, які поняття бізнес і прибуток ставлять в один ряд в повсякденній організації виробництва. Як стверджують науковці та практики, що метод планування $\epsilon$ великим мистецтвом, що визначає подальший успіх підприємства. Адже слід передбачити питання щодо подальшого завоювання ринку, розробка нових видів продукції, вихід на нові ринки, тобто планування повинно грунтуватися на глибоких знаннях ринку і його можливих коливаннях.

Щодо вивчення нами методу управління, який має назву комерційного розрахунку, він являється раціональним і високоефективним методом фінансової діяльності, виступаючи як економічна категорія і одночасно $є$ основним методом управління. Адже, як свідчить практичний досвід, що саме комерційний розрахунок спонукає підприємство до пошуку достатніх i дешевих фінансових ресурсів, раціонального їх розміщення, мінімізації витрат і максимізації доходів та прибутку. Тому комерційний розрахунок сприяє високоефективному господарюванню. Комерційний розрахунок як економічна категорія грунтується на таких принципах:

1. Повна господарська і юридична відокремленість;

2. Самоокупність;

3. Самофінансування;

4. Прибутковість

5. Фінансова відповідальність.

Перелічені нами принципи є взаємозв'язані й становлять єдине ціле, адже як відомо з практики, що в разі недотримання цих взаємозв'язаних принципів не дасть можливості забезпечити дієвий комерційний розрахунок.[5. с.48].

Щодо методу управління - ціноутворення, то дана економічна категорія як метод управління в сучасних умовах $\epsilon$ важливим методом економічного впливу на функціонування всіх ланок господарського механізму. Питання ціноутворення $\epsilon$ принципово важливим, адже ціни на продукцію і послуги повинні встановлювати таким чином щоб реалізована продукція була прибутковою і разом з тим була доступною для покупця. Без виваженого підходу до ціноутворення стає неможливим вирішити питання щодо планування обсягів виробництва, асортименту, потенційних покупців продукції та ін. Як свідчить практика, що підприємство завжди намагається встановлення такої ціни щоб отримати нормальний прибуток, адже як відомо, що основними елементами ціни виробника є собівартість і обов'язково прибуток, саме останній елемент дає можливість забезпечувати розширення виробництва і створювати належні умови для функціонування підприємства.

Щодо організаційно-адміністративних методів управління то ці методи є досить важливими так як тут формуються організаційні відносини трудових ресурсів які $\epsilon$ складовою всього механізму управління на підприємстві. Оскільки через них безпосередньо реалізується одна 3 найважливіших функцій управління - функція організації, то завданням організаційно-адміністративної діяльності є координація дій підлеглих. Вивчаючи питання даного методі приходимо до висновку, що без організаційно-адміністративного впливу не можуть реалізуватися економічні методи управління,, що $\epsilon$ надзвичайно важливим, тому що вони забезпечує чіткість, 
дисциплінованість і порядок роботи колективу. Організаційно-адміністративні методи здійснюють прямий вплив на об'єкт управління через накази, розпорядження, оперативні вказівки, контроль за їх виконанням, систему адміністративних засобів підтримання трудової дисципліни. Ці методи регламентуються правовими актами трудового й господарського законодавства, основною метою яких $є$ правове регулювання відносин між керівником і підлеглим, зміцнення законності, захисту прав і законних інтересів підприємства та його працівників відповідно до Кодексу законів про працю та інших законодавчих актів.[4.c.45]. Підсумовуючи хочемо привернути увагу, що головною метою даного методу управління являється той факт, що він дає можливість до пошуку шляхів і підвищення ефективності господарювання. В період підготовки даної публікації нами вивчалися питання впровадження сукупності методів управління, що нами висвітленні в даній публікації в окремих сільськогосподарських підприємствах Волинської області, для прикладу наведемо результати нашого дослідження, що проводилися у сільгосппідприємстві «Пятидні» Володимир-Волинського району та сільгосппідприємстві ім. Шевченка Горохівського району. Зокрема покажемо в даній статті вплив методів управління на окремих галузях даних підприємств і зокрема галузі зернового господарства та молочній галузі. Як свідчать результати наших досліджень, що в результаті проведених методів планування та розрахунків для забезпечення бажаних результатів прибутковості в сільгосппідприємстві «Пятидні» було збудовано насіннєвий завод для виробництва насіннєвого матеріалу зернових культур з метою одержати більший прибуток у зерновій галузі, а в агропідприємстві ім.. Шевченка Горохівського району, завдяки проведеним розрахункам, прийшли до висновку, що переробка молочної продукції дасть можливість збільшити окупність і забезпечити зростання прибутку. 3 цією метою в даному підприємстві збудовано промислові цехи по переробці молока в яких виробляється готова продукція яка потрапляє до споживачів, що в результаті приносить досить вагомі прибуткові результати. Щодо згаданого в даній публікації побудованого насіннєвого заводу в сільгосппідприємстві «Пятидні» то в ньому виробляється понад 15 тисяч тонн високоякісного насіння. Ефективність і прибутковість за інформацією керівника та спеціалістів даного господарства обчислюється прибавкою урожаю зернових, а саме збільшенням урожайності зернових культур до чотирьох, п’яти центнерів 3 кожного гектара посіву зернових завдяки використанню високоякісного насіння, що вироблено на насіннєвому заводі. Насіннєвий матеріал використовується як для посіву в своєму господарстві, а також продається для потреб інших сільськогосподарських підприємств.

Висновки. В даній статті окреслено суть методів управління як спосіб впливу в досягненні цілей підприємства, що є особливо важливими в період становлення ринкових відносин. Дані методи сьогодні $є$ сукупністю способів і прийомів впливу на колектив працівників та окремих виконавців з метою досягнення встановлених цілей. За їх допомогою орган управління впливає на окремих працівників і підприємство у цілому. В публікації наведені приклади досліджень, що стосується ефективного господарювання окремих сільськогосподарських підприємств Волинської області завдяки широкому застосуванню економічних та організаційно-адміністративних методів управління. Підсумовуючи слід відмітити, що управлінські методи своєю головною метою ставлять забезпечення певних результатів в сучасному підприємстві та розв'язанні соціальних і економних проблем суспільства.

\section{Список бібліографічного опису:}

1.Закон України «Про підприємництво» //Галицькі контракти.- 1998.№8. С.129-159.

2.Загальна економіка: Підручник / За ред. І.Ф.Радіонової - К.- Подільський, 2002. С.101-117.

3. Бойчик І. М., Харів П. С., Хопчпн М. І., Піча Ю. В. Економіка підприємства - К.: "Каравела"; Львів: "Новий світ 2000", 2001. C. 298

4. Грузинов В. П., Грибов В. Д. Экономика предприятия: Учебное пособие. - М.: Финансы и статистика, 1998.С.78-90. 5. Економіка підприємства: Підручник / За заг. ред. С. Ф. Покропивного - Вид 2-ге. - К.: КНЕУ, 2000. С.76-88.

6. Економіка підприємства. Збірник практичних задачі і конкретних ситуацій: Навч. Посібник. / За ред. С. Ф. Покропивного. - К.: КНЕУ, 1999.С.97-106. 
7. Економіка підприємства: Навч. -метод. посібник для самостійного вивчення дисциплін / О. Г. Швиданенко та інші - К.: KHEУ, 2000. С.232-240.

8. Економіка підприємства: Структурно-логічний навч. посібник/ За ред. С. Ф. Покропивного. - К.: КНЕУ, 2001. С.145157.

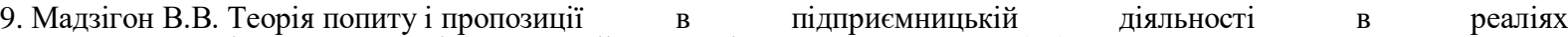
ринкової економіки на товари і послуги. // Молодь і ринок. - 2011. - №2(73). - С. 41 - 46.

10.Я.О. Орищак М.І. Стебло Основи економіки. м. Тернопіль, 1998p. С - 110.

\section{References:}

1. Bondar NM, Makarovskaya TP Business Economics: Textbook. - K .; MAUP, 2003. - 298 p.

2. Bandurka OM, Korobov MI, Orlov PI, Petrova KY Financial activity of the enterprise: Textbook. - K .: Libid, 1998. - 312

3. Belevtsev MI, Shestopalova. Commodity Market Infrastructure: A Textbook. - K., 2005 - 410 p.

4. Birman L. Economics of the firm. Tutorial. M.: M / n Univ. and Management, 2001-104s.

5. Blank IA Trade management. - K .: Ukrainian-Finnish Institute of Management and Business, 1997. - 408 p.

6 .Golubkov EP Marketing researches. Theory and methodology. K .: ASK, 2000. - 221 p.

7. VG Zhmalev, LM Shimanovskaya. Fundamentals of Management and Management. - K .: Ukraine, 2000. - 454 p.

8. Izmailova KV Financial Analysis: Educ. - K .: MAUP, 2001. With 40-42.

9. Z. Kryhovetska, II Tsygylik, and TM Panik. Fundamentals of entrepreneurship. Educ. Manual. - K. 2005. - 239 p.

10. Kardash V.Ya. Commodity Marketing Policy: Educ. - Method. a guide for loneliness. study diss. - K: KNEU, 2000. - 124

11. Sidorenko OI, Redko PS Management: situational exercises: teaching. Toolkit: Situational Learning Dissemination Program - K .: Consortium for Improving Management Education in Ukraine, 2004. - 465 p.

Рецензент д.е.н., професор Ковальська Л.Л.

УДК 005.334:339.137

Дашко I. М. к.е.н., доцент кафедри обліку та менеджменту

Криворізький факультет

Запорізького національного університету

\section{АНТИКРИЗОВЕ УПРАВЛІННЯ В СИСТЕМІ ЗАБЕЗПЕЧЕННЯ КОНКУРЕНТОСПРОМОЖНОСТІ ПІДПРИСМСТВА}

Підприємство є цілісна система та складається з взаємозалежних елементів, зв’язків і відносин між ними. Проаналізовано теоретичні підходи щодо антикризового управління в контексті забезпечення конкурентоспроможності. Кризові явища унеможливлюють розвиток підприємницької діяльності підприємства і відповідно його конкурентоспроможність. Відповідно до системоузгодженості елементів підприємства обгрунтовано адаптацію механізму антикризового управління підприємством щодо забезпечення конкурентоспроможності. Поєднання сутнісних елементів антикризового управління та конкурентних позицій підприємств є підгрунтя створення синергетичних ефектів щодо забезпечення конкурентоспроможності в умовах кризових явищ.

Ключові слова: антикризове управління, конкурентоспроможність, ризик, підприємство, моніторинг, діагностика

Dashko I.

\section{ANTI-CRISIS MANAGEMENT IN THE SYSTEM OF ENTERPRISE COMPETITIVENESS}

An enterprise is a holistic system and consists of interdependent elements, relationships and relationships between them. The combination of essential elements of anti-crisis management and the competitive position of enterprises is the basis for creating synergistic effects on ensuring competitiveness in a crisis. Theoretical approaches to crisis management in the context of competitiveness are analyzed. Crisis phenomena make it impossible to develop the enterprise activity of the enterprise and, accordingly, its competitiveness. In accordance with the systematic coherence of the elements of the enterprise, the adaptation of the anti-crisis management mechanism of the enterprise to ensure competitiveness is substantiated.

Keywords: anti-crisis management, competitiveness, risk, enterprise, monitoring, diagnostics

Дашко И. М.

\section{АНТИКРИЗИСНОЕ УПРАВЛЕНИЕ В СИСТЕМЕ ОБЕСПЕЧЕНИЯ КОНКУРЕНТОСПОСОБНОСТИ ПРЕДПРИЯТИЯ}

